\title{
INTEgrated Project management Measures IN CMMI
}

\author{
Mahmoud Khraiwesh \\ Faculty of Information Technology, Zarqa University, Zarqa - Jordan
}

\begin{abstract}
Project management is quite important to execute projects effectively and efficiently. Project management is vital to projects success. The main challenge of project management is to achieve all project goals, taking into consideration time, scope, budget constraints, and quality. This paper will identify general measures for the two specific goals and its ten specific practices of Integrated Project management Process Area in Capability Maturity Model Integration (CMMI). CMMI is a framework for improvement and assessment of computer information systems. The method we used to define the measures is to apply the Goal Questions Metrics (GQM) paradigm to the two specific goals and its ten specific practices of Integrated Project management Process Area in CMMI.
\end{abstract}

\section{KEYWORDS}

Project, Management, Measures, CMMI, GQM.

\section{INTRODUCTION}

Integrated project management (IPM) establishes and manages the project and the relevant stakeholders according to defined and integrated process based on the standard processes of the organization [35]. Project management is the process of planning, motivating and controlling procedures and resources to achieve specific goals.

Project management is "the application of knowledge, skills, tools and techniques to project activities to meet project requirements" [26]. Project management includes the processes that plan, initiate, execute, close, and control work. Through these processes, tradeoffs must be made between the following factors: resources, scope, cost, quality, schedule, and risks [26].

The use of project management has increased rapidly and is likely keep increasing. With growing international competition, customers need to have their services and products developed and delivered faster, better, and cheaper. Because project management methods are designed to manage quality, scope, cost, and schedule, they are ideally suitable for this purpose [26].

The cost of coming projects depends on the project management maturity level [36]. Project management has been used to attack the problems of scheduling, staffing, effort estimation, and risk. Project management can help to solve the optimization problems which are faced by the manager [10].

The following activities in project management are critical for the success of a project: cost estimation, project planning, and quality management [10]. A normal goal of project management is to find project plans that minimize the project's completion time. Another goal that has been taken into account is to reduce the risks related to the development process such as reducing budgets [10]. 
Project management is effective and vital in executing sustainable projects [14]. The capability maturity model integrated (CMMI) is established to support organizations to enhance project management and to choose effective and efficient project management practices [Wang, et al., 2013]. Many computer information systems projects go wrong because of the lack of good management of the projects [14].

Software project measures ensure that the project is under control. Measurements of a software project apply to processes, products, and people [6]. Nowadays we know that software measurement helps us to better control, understand, and evaluate the processes, products, and software projects from the perspective of controlling, understanding, evaluating, tracking, and forecasting [11]. A valid measurement process can provide companies with better decisions to achieve success in software development projects [17].

Measurement is a useful support approach for project management [25]. Measurement is important for efficient management of processes. Measurement is a technique for identifying, evaluating, and predicting for multiple software processes and products [1]. To improve a software process we should determine specific attributes of the process then define related metrics based on these attributes of the process, and then use the defined metrics to improve the process. Measurements approach does an important function in understanding and controlling processes and products in software development [24].

"During software measurement we assign numbers or symbols to attributes of the selected entities in the real life in such a way to identify the attributes by some defined rules" Fenton and others said [9]. Measurement is important for understanding, controlling, and improvement [8]. Measurements are used to determine status according to plans, to assess achievement of goals, to gain understanding of processes, products, and resources, to establish principles for comparisons with future evaluations, and to follow up improvement process [31]. The important measurement objective is to control and monitor the execution of software development processes [29].

For the time being software measurement is in a step in which terminologies, principles, and methods are still being defined and joined. We should not expect to reach quantitative laws that are primarily valid and usable, and have the same regularity and precisions as the laws of physics. The identification of applicable metrics that are global valid may be long term research goal, which cannot be concluded in the closer future [5]. Precise measures such as temperature, mass, voltage or velocity are unusual in the software engineering field. Software measurements are often indirect so, they are open to disagreement [33]. There is lack of agreement framework of validation metrics [15]. The objective of software measures is to enhance the development of software [7].

The Software Engineering Institute (SEI) started a research to recognize the capability of software developers in the mid 1980s. The outcome of the study was the development of Software Capability Maturity Model for Software (CMM/SW) [32]. Software Engineering Institute (SEI) and some other companies in the same field are cooperating to develop the Capability Maturity Model Integrated (CMMI) framework. The CMMI is an extensive framework and used vastly for improving the processes of companies that produce efficient products [34].

CMMI model provides technical instructions to achieve a specific level of process development quality. The main goal of CMMI is to increase the quality the software products according to the agreed user's requirements. Using models such as CMMI model to enhance and assess quality of software is a minimum need for organization's survival and also an organization strategy [30]. 
During the process of using CMMI, we try to achieve the following objectives: enhancing management of the project, improving product quality, cost down, increasing productivity, and enhancing the ability of estimating the budget and schedule of the project [27].

CMMI includes a lot of subjects related to software development processes. CMMI specifies many Process Areas (PA). Each process area has generic goals and generic practices, specific goals and specific practices, and many related work products. CMMI objectives are to enhance processes, increase production, and increase competitive product of organizations [41]. CMMI is used in appraisal as the basis for deciding the satisfaction of a process area has. CMMI framework is a well structured improvement model which clearly defines its practices and activities in an easy way [18].

Each selected process area in CMMI model has generic goals and related generic practices. Each process area has specific goals and related specific practices. A specific goal focuses on the characteristics that describe what must be done to satisfy the process area. A specific practice is a main activity in realizing the associated specific goal. In fact, specific practices are known by CMMI as goals rather than the technique that we reach the goal [38].

CMMI framework helps in setting goals for process improvement and provides guidance for process quality. The CMMI framework covers all processes in the project development life cycle and involves a wide range of processes and products [39].

Capability maturity model integration (CMMI) is becoming quite popular internationally as an industry standard of software process improvement because of the level of breadth and details covered [37]. CMMI (capability maturity model integration) is a process framework which is organized by process areas, goals, and practices [40].

Goal-Question-Metric (GQM) is an approach for defining process metrics. GQM was developed by Basili and Weiss [3] for identifying reliable metrics for software development processes. GQM has confirmed that it is an effective approach to select and implement metrics.

This research identifies measures for the two specific goals and ten specific practices of Integrated Project Management. Integrated Project Management is one of the process areas in level 3 in CMMI-SW (Staged Representation) model. The defined measures will be proper with the ten specific practices associated with the two specific goals of Integrated Project Management PA. We will define the measures by applying the Goal-Question-Metrics (GQM) method to the two specific goals and its ten specific practices of Integrated Project Management PA. The defined measures will be useful for evaluation and control of the products and processes in Integrated Project Management.

The organization of the remainder of the paper is: section two describes the software processes measurement of CMM/SW and CMMI related work, section three and four describe overview of the CMMI/SW and GQM, section five shows the application of the GQM to the CMMI and defines the measures, section six describes the validity and reliability of the defined measures for Integrated Project Management process area, and section seven shows conclusions.

\section{RELATED WORK}

Many software process measures researches have been proposed in the literature, some of them are [4] [13] [16] [19] [20] [21] [22] [23] [28] [32]. The most related to our work are [4] [28] [32] [19] [20] [21] [22] and [23]. The study of Baumert and McWhinney [4] determines a set of indicators that are convenient with the measurement practice (a common features) described in 
the Capability Maturity Model for $\mathrm{CMM} / \mathrm{SW}$. The identified indicators involve thirteen categories; categories don't occur at all of the maturity levels. Baumert and McWhinney work don't focus on a specific process. There work was concerning to CMM not CMMI.

Paulk and others [32] define a set of examples of metrics in measurement practice (one of the common features) of the Capability Maturity Model for Software (CMM/SW) in Key Process Areas (KPAs). In their work they defined a few examples concerned to requirements management KPA. They don't focus on a specific process. Their work was based on $(\mathrm{CMM} / \mathrm{SW})$ not on (CMMI/SW). In Loconsole works 28] a set of measures for the Requirements Management Key Process Area of the CMM/SW were defined. Her work was related to $(\mathrm{CMM} / \mathrm{SW})$ not on (CMMI/SW). In Khraiwesh works [19] [20] [21] [22] [23] a set of measures were defined for Requirements Validation, Risk Management, Project Planning, Project Monitoring and Control, and Process and Product Quality Assurance process areas of the CMMI/SW.

This paper defines a set of generic measures that are related to Integrated Project Management $\mathrm{PA}$ in CMMI/SW. The defined measures are related to the two specific goals and the related ten specific practices of Integrated Project Management Process Area.

\section{OVERVIEW OF THE CMMI-SW}

The CMMI/SW (Staged Representation) includes five levels of maturity: Initial, Managed, Defined, Quantitatively Managed and Optimizing. Each of the levels contains several process areas excluding level1 [35]. As shown in Figure 1.

Each of the process areas in $(\mathrm{CMMI} / \mathrm{SW})$ has generic goals with related generic practices. Each process area has one or more specific goals with related specific practices. The generic goal has appropriate institutionalization practices, they called generic because the one goal related to multiple process areas. As shown in figure 2. The specific goal is related to a specific process area and manages the features that only describe what must be executed to complete the process area. A practice is an action that must be executed to finish the related specific goal [35].

The purpose of Integrated Project Management (IPM) is to establish and manage the project and the relevant stakeholders according to defined and integrated process based on the standard processes followed in the organization [35].

The following is a list of the specific goals related to Integrated Project Management process area and the specific practices related to each specific goal: 
International Journal of Computer Science \& Information Technology (IJCSIT) Vol 7, No 5, October 2015

1- Use the Project's Defined Process:-

1.1 Establish the Project's Defined Process.

1.2 Use Organizational Process Assets for Planning Project Activities.

1.3 Establish the Project's Work Environment.

1.4 Integrate Plans.

1.5 Manage the Project Using Integrated Plans.

1.6 Establish Teams.

1.7 Contribute to Organizational Process Assets.

2- Coordinate and Collaborate with Relevant Stakeholders:-

2.1 Manage Stakeholder Involvement.

2.2 Manage Dependencies.

2.3 Resolve Coordination Issues.

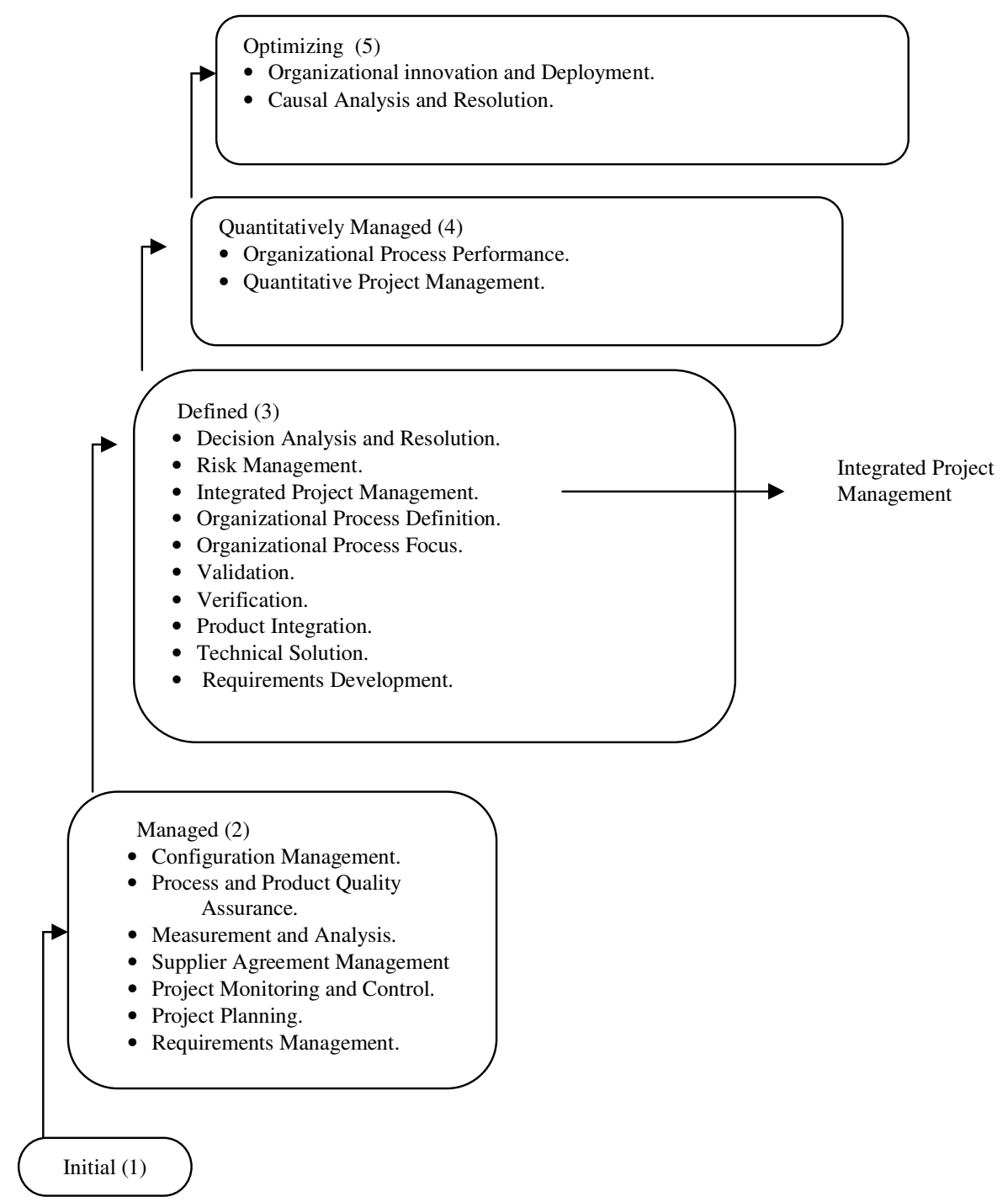

Figure 1. The five levels of maturity in CMMI with related Process Areas 


\section{OVERVIEW OF THE GQM}

The Goal/Question/Metric (GQM) model is a process which supports organizations to focus on the measurement of their goals. GQM paradigm requires that an organization should define goals before collecting data [1]. The more mature process the more obvious and easy to be measured. GQM defines goals then generates set of quantifiable questions related to the goals then defines a set of measures related to the questions then collect data which lead to realize the goals.

The GQM paradigm consists of three steps:

1. Define a group of specified goals related to the needs of the organization's projects. The set of specified goals can be determines as purpose, perspective, and environment. Measurement goals should be defined in structural and an understandable way. We determines the purpose (what goal and why), viewpoint (what aspect and who), and characteristics of context [2].

2. Generate a group of quantifiable questions. The set of specified goals are moved to quantifiable questions with a concentration on measurement. Basili and Rombach [1] define several sets of instructions to classify questions associated to processes or products.

3. Determine a set of measures that are suitable for the quantitative information we need to answer the defined quantifiable questions. In this stage, we define measures that provide information to answer the questions. Several metrics may be defined for one goal. One measurement may apply to several questions

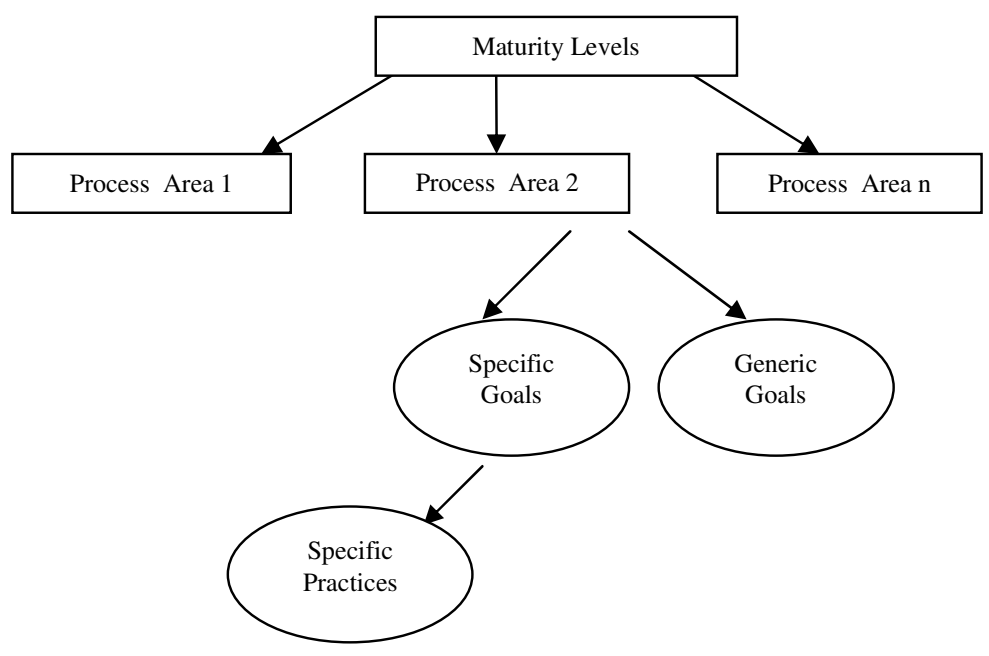

Figure 2. Specific and generic goals

\section{APPLYING GQM to The CMMI-SW}

The CMMI/SW defines two specific goals for Integrated Project Management process area and ten specific practices related to the two specific goals. We consider the specific practices as goals. The ten specific practices will be applied on the GQM method.

The ten specific practices associated with Integrated Project Management process area are: 
1- Establish the Project's Defined Process: Establish and maintain the defined process of the project from project startup through the life of the project.

2- Use Organizational Process Assets for Planning Project Activities: Use organizational process assets and the measurement repository for planning and estimating project activities.

3- Establish the Project's Work Environment: Establish and maintain the project's work environment based on the organization's work environment standards.

4- Integrate Plans: Integrate the project plan and other plans that affect the project to describe the defined process of the project.

5- Manage the Project Using Integrated Plans: Manage the project using the project plan, other plans that affect the project, and the defined process of the project.

6- Establish Teams: Establish and maintain teams.

7- Contribute to Organizational Process Assets: Contribute process related experiences to organizational process assets.

8- Manage Stakeholder Involvement: Manage the involvement of relevant stakeholders in the project.

9- Manage Dependencies: Participate with relevant stakeholders to negotiate, identify, and track critical dependencies.

10- Resolve Coordination Issues: Resolve issues with relevant stakeholders.

These ten specific practices can be used as goals for the first step of the GQM. The next step in the GQM method is to generate a collection of quantifiable questions related to the ten specific practices. The third step of the GQM is to identify a set of measures that provide the needed quantitative information to answer the generated questions. The work products and sub practices which are suggested in each of the ten specific practices are take into account when we define the measures.

A combination of questions and measures are given in the next tables, table 1 to table 10. Each table represents one specific practice, there are interfering between the questions and between the measures. The same measure can be used to provide information to answer different generated questions.

\subsection{Measures for specific practice 1.}

Establish the Project's Defined Process: Establish and maintain the defined process of the project from project startup through the life of the project.

Questions and measures which are given in the following table related to specific practice 1 in IPM.

Table 1. Questions and measures related to specific practice 1 in IPM.

\begin{tabular}{|l|l|l|}
\hline & Questions & Measures \\
\hline Q1 & $\begin{array}{l}\text { Do you establish and maintain the defined } \\
\text { process of the project from project startup } \\
\text { through the life of the project? }\end{array}$ & $\begin{array}{l}\text { Establishing and maintaining the defined } \\
\text { process of the project. } \\
\text { \# Days the life of the project. } \\
\text { (\# means number of })\end{array}$ \\
\hline Q2 & $\begin{array}{l}\text { Do you define the project processes based } \\
\text { on stakeholder requirements, commitments, } \\
\text { organizational process needs and objectives? }\end{array}$ & $\begin{array}{l}\text { - Defining the project processes based on } \\
\text { stakeholder requirements. } \\
\text { \# Stakeholder requirements. }\end{array}$ \\
\hline
\end{tabular}




\begin{tabular}{|c|c|c|}
\hline Q3 & $\begin{array}{l}\text { Do you define the project processes based } \\
\text { on organization's set of standard processes? }\end{array}$ & $\begin{array}{l}\text { - Defining the project processes based on } \\
\text { standard processes. } \\
\text { - \# Standard processes. }\end{array}$ \\
\hline Q4 & $\begin{array}{l}\text { Do you define the project processes based } \\
\text { on business environment and operational } \\
\text { environment? }\end{array}$ & $\begin{array}{l}\text { - Defining the project processes based on } \\
\text { business environment and operational } \\
\text { environment. }\end{array}$ \\
\hline Q5 & $\begin{array}{l}\text { Do you elaborate and revise the defined } \\
\text { processes as the project progresses to meet } \\
\text { project requirements and organization's } \\
\text { process needs and objectives? }\end{array}$ & $\begin{array}{l}\text { - Elaborating and revising the defined } \\
\text { processes as the project progresses. } \\
\text { - \# Project requirements. } \\
\text { - \# Organizational objectives }\end{array}$ \\
\hline Q6 & $\begin{array}{l}\text { Do you select a lifecycle model from the } \\
\text { available ones in organizational process } \\
\text { assets? }\end{array}$ & $\begin{array}{l}\text { - Selecting a lifecycle model. } \\
\text { - \# lifecycle models. }\end{array}$ \\
\hline Q7 & $\begin{array}{l}\text { Do you choose the proper lifecycle model } \\
\text { based on project characteristics such as: } \\
\text { complexity and size of the project, } \\
\text { experience of implementing the process, } \\
\text { cycle time constraints, acceptable defect } \\
\text { level, and clarity of requirements? }\end{array}$ & $\begin{array}{l}\text { - Choosing the proper lifecycle model based on } \\
\text { project characteristics. } \\
\text { - Size of the project. } \\
\text { - } \quad \text { Complexity of the project. } \\
\text { - } \quad \text { Defect level. } \\
\text { - Level of clarity of requirements. }\end{array}$ \\
\hline Q8 & $\begin{array}{l}\text { Use artifacts from the organization's process } \\
\text { asset library such as: templates and example } \\
\text { documents? }\end{array}$ & $\begin{array}{l}\text { - Using artifacts from the organization's } \\
\text { process asset library. } \\
\text { - \# Templates. } \\
\text { - \# Example documents. }\end{array}$ \\
\hline Q9 & $\begin{array}{l}\text { Do you document the project's defined } \\
\text { process? }\end{array}$ & - $\quad$ Documenting the project's defined process. \\
\hline $\begin{array}{l}\text { Q1 } \\
0\end{array}$ & $\begin{array}{l}\text { Does the project defined process covers all } \\
\text { activities of the project and interfaces with } \\
\text { stakeholders such as: project planning, } \\
\text { project monitoring quality assurance, } \\
\text { requirements development, requirements } \\
\text { management, and configuration } \\
\text { management? }\end{array}$ & $\begin{array}{l}\text { - Covering all activities of the project and } \\
\text { interfaces with stakeholders. } \\
\text { - \# covered activities. }\end{array}$ \\
\hline $\begin{array}{l}\text { Q1 } \\
1\end{array}$ & $\begin{array}{l}\text { Do you conduct peer reviews of the } \\
\text { project's defined process? }\end{array}$ & $\begin{array}{l}\text { - Conducting peer reviews of the project's } \\
\text { defined process. }\end{array}$ \\
\hline
\end{tabular}

\subsection{Measures for specific practice 2 .}

Use Organizational Process Assets for Planning Project Activities: Use organizational process assets and the measurement repository for planning and estimating project activities.

Questions and measures which are given in the following table related to specific practice 2 in IPM.

Table 2. Questions and measures related to specific practice 2 in IPM

\begin{tabular}{|l|l|l|}
\hline & Questions & Measures \\
\hline Q1 & $\begin{array}{l}\text { Do you use organizational process assets for } \\
\text { estimating and planning project activities? }\end{array}$ & $\begin{array}{l}\text { Using of organizational process assets for } \\
\end{array}$ \\
& $\begin{array}{l}\text { estimating and planning project activities. } \\
\text { \# Estimated project activities. }\end{array}$ \\
\hline
\end{tabular}




\begin{tabular}{|c|c|c|}
\hline Q2 & $\begin{array}{l}\text { Do you use organizational measurement } \\
\text { repository for estimating and planning project } \\
\text { activities? }\end{array}$ & $\begin{array}{l}\text { - Using of organizational measurement } \\
\text { repository for estimating and planning } \\
\text { project activities. } \\
\text { - \# used organizational measurement } \\
\text { repository. }\end{array}$ \\
\hline Q3 & $\begin{array}{l}\text { Do you use work products and tasks of the } \\
\text { defined process of the project as a basis for } \\
\text { estimating and planning project activities? }\end{array}$ & $\begin{array}{l}\text { - Using work products and tasks of the defined } \\
\text { process of the project as a basis for } \\
\text { estimating and planning. } \\
\text { - \# Work products. } \\
\text { - \# Tasks. }\end{array}$ \\
\hline Q4 & $\begin{array}{l}\text { Do you use the measurement repository of the } \\
\text { organization in estimating the project's } \\
\text { planning parameters? (Measurement } \\
\text { repository examples include: size of work } \\
\text { product, effort, cost, schedule, staffing, and } \\
\text { defects) } \\
\text { (Estimate examples include: historical data } \\
\text { from similar projects, reasoning of } \\
\text { experienced project participants) }\end{array}$ & $\begin{array}{l}\text { - Using the measurement repository of the } \\
\text { organization in estimating the planning } \\
\text { parameters of the project. } \\
\text { - Size of work products. } \\
\text { - Cost. } \\
\text { - Duration of the project. } \\
\text { - \# Staff. } \\
\text { - \# Defects. } \\
\text { - \# experienced project participants. }\end{array}$ \\
\hline Q5 & $\begin{array}{l}\text { Do you consider some parameters for } \\
\text { similarities and differences of projects, such } \\
\text { as: work product, application domain, and } \\
\text { experience of the people, design and } \\
\text { development approaches, and operational } \\
\text { environment? }\end{array}$ & $\begin{array}{l}\text { - Considering some parameters for similarities } \\
\text { and differences of projects. } \\
\text { - \# work products. } \\
\text { - Level of experience of the people. } \\
\text { - \# Design and development approaches. }\end{array}$ \\
\hline
\end{tabular}

\subsection{Measures for specific practice 3 .}

Establish the Project's Work Environment: Establish and maintain the project's work environment based on the organization's work environment standards.

Questions and measures which are given in the following table related specific practice 3 in IPM.

Table 3. Questions and measures related to specific practice 3 in IPM.

\begin{tabular}{|c|l|l|}
\hline Q1 & Questions & $\begin{array}{l}\text { Measures } \\
\text { Do you establish and maintain the work } \\
\text { environment of the project based on the } \\
\text { work environment standards of the } \\
\text { organization? } \\
\text { (Work environment examples include: } \\
\text { infrastructure of facilities, tools, and } \\
\text { equipment that people need to perform } \\
\text { their jobs effectively). } \\
\text { (Examples of tools and equipment } \\
\text { include: decision support software, } \\
\text { office software, project management } \\
\text { tool, test and evaluation equipment, } \\
\text { requirement management tool, and } \\
\text { integration tool). }\end{array}$ \\
\hline Q2 & $\begin{array}{l}\text { Establishing and maintaining the work } \\
\text { environment of the project based on the } \\
\text { work environment standards of the } \\
\text { organization. } \\
\text { \# Tools. }\end{array}$ \\
$\begin{array}{l}\text { Do you plan, design, and install a work } \\
\text { environment for the project? }\end{array}$ & $\bullet \begin{array}{l}\text { Planning, designing, and installing a work } \\
\text { environment for the project. }\end{array}$ \\
\hline
\end{tabular}




\begin{tabular}{|c|l|l|}
\hline Q3 & $\begin{array}{l}\text { Do you provide ongoing maintenance and } \\
\text { operational support of the project's work } \\
\text { environment? } \\
\text { (Examples of maintenance and operational } \\
\text { support include: hiring people to perform } \\
\text { maintenance support, training people, } \\
\text { contracting, or developing expert users for } \\
\text { selected tools). }\end{array}$ & $\begin{array}{l}\text { - } \begin{array}{l}\text { Provide ongoing maintenance and } \\
\text { operational support of the project's work } \\
\text { environment. }\end{array} \\
\text { Q \# Hired people to perform maintenance } \\
\text { support. }\end{array}$ \\
\hline Q4 & $\begin{array}{l}\text { Do you maintain the qualification of } \\
\text { components of the project's environment? } \\
\text { (Components include: Software data bases, } \\
\text { hardware, tools and documentation)? }\end{array}$ & $\begin{array}{l}\text { - } \begin{array}{l}\text { Maintaining the qualification of components } \\
\text { of the environment of the project. }\end{array} \\
\text { environment. }\end{array}$ \\
\hline Q5 & $\begin{array}{l}\text { Do you periodically review how well the } \\
\text { work environment is meeting project needs } \\
\text { and take action as appropriate? }\end{array}$ & $\begin{array}{l}\text { - Reviewing periodically how well the work } \\
\text { environment is meeting project needs. } \\
\text { and }\end{array}$ \\
\hline
\end{tabular}

\subsection{Measures for specific practice 4 .}

Integrate Plans: Combine the project plan and other plans that affect the project to describe the defined process of the project.

Questions and measures which are given in the following table related to specific practice 4 in IPM.

Table 4. Questions and measures related to practice 4 in IPM.

\begin{tabular}{|l|l|l|}
\hline Q1 & $\begin{array}{l}\text { Questions } \\
\text { plans that affect the project to describe the } \\
\text { defined process of the project? }\end{array}$ & $\begin{array}{l}\text { Measures } \\
\bullet \text { \# plans. }\end{array}$ \\
\hline Q2 & $\begin{array}{l}\text { Do you integrate the project plan with quality } \\
\text { assurance plan? }\end{array}$ & $\begin{array}{l}\text { - Integrating the project plan with quality } \\
\text { assurance plan. }\end{array}$ \\
\hline Q3 & $\begin{array}{l}\text { Do you integrate the project plan with risk } \\
\text { management strategy? }\end{array}$ & $\begin{array}{l}\text { Integrating the project plan with risk } \\
\text { management strategy. } \\
\text { Q \# Risks. }\end{array}$ \\
\hline Q4 & $\begin{array}{l}\text { Do you integrate the project plan with } \\
\text { verification and validation plan? }\end{array}$ & $\begin{array}{l}\text { - Integrating the project plan with verification } \\
\text { and validation plan. }\end{array}$ \\
\hline Q5 & $\begin{array}{l}\text { Do you integrate the project plan with staff } \\
\text { training plan? }\end{array}$ & $\begin{array}{l}\text { Integrating the project plan with staff } \\
\text { training plan. } \\
\text { Q \# Trained staff. }\end{array}$ \\
\hline Q6 & $\begin{array}{l}\text { Do you integrate the project plan with } \\
\text { configuration management? }\end{array}$ & $\begin{array}{l}\text { - Integrating the project plan with } \\
\text { configuration management plan. } \\
\text { Documentation plan? }\end{array}$ \\
\hline
\end{tabular}




\begin{tabular}{|l|l|l|}
\hline Q8 & $\begin{array}{l}\text { Do you incorporate into the project plan } \\
\text { measurement activities for managing the } \\
\text { project? }\end{array}$ & $\begin{array}{l}\text { - Incorporating into the project plan } \\
\text { measurement activities for managing the } \\
\text { project. }\end{array}$ \\
\hline Q9 & $\begin{array}{l}\text { Do you identify and analyze product and } \\
\text { project interface risks? } \\
\text { (Example of product and project interface } \\
\text { risks: unavailability tools inadequate team } \\
\text { interfaces, unavailability of COTS } \\
\text { components) }\end{array}$ & $\begin{array}{l}\text { - Identifying and analyzing product and } \\
\text { project interface risks. } \\
\text { \# Interface risks. }\end{array}$ \\
\hline Q10 & $\begin{array}{l}\text { Do you ensure that the project plan is proper } \\
\text { with the plans of stakeholders? }\end{array}$ & $\begin{array}{l}\text { - Ensuring that the project plan is proper with } \\
\text { the plans of stakeholders. }\end{array}$ \\
\hline
\end{tabular}

\subsection{Measures for specific practice 5 .}

Manage the Project Using Integrated Plans: Manage the project using the project plan, other plans that impact the project, and the defined process of the project.

Questions and measures which are given in the following table related to specific practice 5 in IPM.

Table 5. Questions and measures related to practice 5in IPM

\begin{tabular}{|c|c|c|}
\hline & Questions & Measures \\
\hline Q1 & $\begin{array}{l}\text { Do you manage the project using the project } \\
\text { plan, other plans, and the project's defined } \\
\text { process? }\end{array}$ & $\begin{array}{l}\text { - Managing the project using the project plan, } \\
\text { other plans, and the project's defined } \\
\text { process. } \\
\text { - \# plans. }\end{array}$ \\
\hline Q2 & $\begin{array}{l}\text { Do you implement the project's defined } \\
\text { process using organization's process asset } \\
\text { library? }\end{array}$ & $\begin{array}{l}\text { - Implementing the defined process of the } \\
\text { project using organization's process asset } \\
\text { library. }\end{array}$ \\
\hline Q3 & $\begin{array}{l}\text { Do you monitor and control the project's } \\
\text { activities and work products using the } \\
\text { projects defined process, project plan, and } \\
\text { other plan that affects the project? }\end{array}$ & $\begin{array}{l}\text { - Monitoring and controlling the project's } \\
\text { activities and work products. } \\
\text { - \# Project activities. } \\
\text { - \# Work products. }\end{array}$ \\
\hline Q4 & $\begin{array}{l}\text { Do you track project planning parameters } \\
\text { using measurable threshold that will trigger } \\
\text { appropriate actions? }\end{array}$ & $\begin{array}{l}\text { - Tracking project planning parameters using } \\
\text { measurable threshold. } \\
\text { - \# Parameters. } \\
\text { - Threshold. }\end{array}$ \\
\hline Q5 & $\begin{array}{l}\text { Do you monitor product and project interface } \\
\text { risks? }\end{array}$ & $\begin{array}{l}\text { - Monitoring product and project interface } \\
\text { risks. } \\
\text { - \# interface risks }\end{array}$ \\
\hline Q6 & $\begin{array}{l}\text { Do you manage internal and external } \\
\text { commitments based on plans for work } \\
\text { products and tasks? }\end{array}$ & $\begin{array}{l}\text { - Managing external and internal } \\
\text { commitments. } \\
\text { - \# Work products. }\end{array}$ \\
\hline Q7 & $\begin{array}{l}\text { Do you get and analyze selected } \\
\text { measurements to support organization needs } \\
\text { and manage the project? }\end{array}$ & $\begin{array}{l}\text { - Getting and analyzing selected } \\
\text { measurements. }\end{array}$ \\
\hline Q8 & $\begin{array}{l}\text { Do you periodically review and align the } \\
\text { project's performance with current needs, } \\
\text { objectives, and requirements of the } \\
\text { organization? }\end{array}$ & $\begin{array}{l}\text { - Reviewing and aligning the project's } \\
\text { performance with current needs, objectives, } \\
\text { and requirements of the organization } \\
\text { periodically. }\end{array}$ \\
\hline
\end{tabular}




\begin{tabular}{|l|l|l|}
\hline Q9 & $\begin{array}{l}\text { Do you change the schedule with proper } \\
\text { modifications to other planning parameters } \\
\text { and project risks? }\end{array}$ & $\begin{array}{l}\text { - Changing the schedule with proper } \\
\text { modifications to other planning parameters } \\
\text { and project risks. } \\
\text { - \# Adjustments. }\end{array}$ \\
\hline Q10 & $\begin{array}{l}\text { Do you change system requirements or } \\
\text { commitments in response to market chances } \\
\text { or a change in customer needs? }\end{array}$ & $\begin{array}{l}\text { - Changing system requirements or } \\
\text { commitments in response to market chance } \\
\text { or a change in customer needs. } \\
\text { - \# Changed requirements. }\end{array}$ \\
\hline Q11 & $\begin{array}{l}\text { Do you terminate the project, iteration, or } \\
\text { release if needed? }\end{array}$ & $\begin{array}{l}\text { - Terminating the project, iteration, or } \\
\text { releasing if needed. }\end{array}$ \\
\hline Q12 & $\begin{array}{l}\text { Do you determine and analyze issues that } \\
\text { require corrective action to determine how to } \\
\text { prevent recurrence for issues that affect } \\
\text { project objective? }\end{array}$ & $\begin{array}{l}\text { - Determining and analyzing issues that } \\
\text { require corrective action. } \\
\text { - \# Issues that require corrective action. }\end{array}$ \\
\hline
\end{tabular}

\subsection{Measures for specific practice 6 .}

Establish Teams: Establish and maintain teams.

Questions and measures which are given in the following table related to specific practice 6 in IPM.

Table 6. Questions and measures related to practice 6 in IPM.

\begin{tabular}{|c|c|c|}
\hline & Questions & Measures \\
\hline Q1 & Do you establish and maintain project teams? & $\begin{array}{l}\text { - Establishing and maintaining project teams. } \\
\text { - \# Team members. }\end{array}$ \\
\hline Q2 & $\begin{array}{l}\text { Do you include relevant stakeholders on the } \\
\text { team? }\end{array}$ & $\begin{array}{l}\text { - Including relevant stakeholders on the team. } \\
\text { - \# Relevant stakeholders. }\end{array}$ \\
\hline Q3 & $\begin{array}{l}\text { Do you establish a team which represents all } \\
\text { parts that effect overall success? }\end{array}$ & $\begin{array}{l}\text { - Establishing a team which represents from } \\
\text { all parts that effect overall success. } \\
\text { - \# Team members from each party. }\end{array}$ \\
\hline Q4 & $\begin{array}{l}\text { Do you establish and maintain project's } \\
\text { shared vision by understanding the interface } \\
\text { between all parties that affect the project? }\end{array}$ & $\begin{array}{l}\text { - Establishing and maintaining project's } \\
\text { shared vision. } \\
\text { - \# Parties that affect the project. }\end{array}$ \\
\hline Q5 & $\begin{array}{l}\text { Do you establish a suitable team structure } \\
\text { including team authorities, responsibilities, } \\
\text { and interrelationships? }\end{array}$ & $\begin{array}{l}\text { - Establishing a suitable team structure } \\
\text { including team authorities, responsibilities, } \\
\text { and interrelationships. } \\
\text { - \# Team interrelationships. }\end{array}$ \\
\hline Q6 & $\begin{array}{l}\text { Do you provide the team by resources } \\
\text { required to accomplish the tasks assigned to } \\
\text { the team? }\end{array}$ & $\begin{array}{l}\text { - Providing the team by resources required to } \\
\text { accomplish the tasks. } \\
\text { - \# Tasks assigned to the team. }\end{array}$ \\
\hline Q7 & $\begin{array}{l}\text { Do you evaluate the team structure and } \\
\text { composition periodically? }\end{array}$ & $\begin{array}{l}\text { - Evaluating the team structure and } \\
\text { composition periodically. } \\
\text { - The period to evaluate the team structure. }\end{array}$ \\
\hline
\end{tabular}

\subsection{Measures for specific practice 7 .}

Contribute to Organizational Process Assets: Participate process related experiences with organizational process assets. 
International Journal of Computer Science \& Information Technology (IJCSIT) Vol 7, No 5, October 2015

Questions and measures which are given in the following table related to specific practice 7 in IPM.

Table 7. Questions and measures related to practice 7 in IPM.

\begin{tabular}{|l|l|l|}
\hline & Questions & Measures \\
\hline Q1 & $\begin{array}{l}\text { Do you contribute process related } \\
\text { experiences to organizational process assets? }\end{array}$ & $\begin{array}{l}\text { - Contributing process related experiences to } \\
\text { organizational process assets. }\end{array}$ \\
\hline Q2 & $\begin{array}{l}\text { Do you propose improvements to the } \\
\text { organizational process assets? }\end{array}$ & $\begin{array}{l}\text { - Proposing improvements to the } \\
\text { organizational process assets. } \\
\text { Q \# Proposed improvements. }\end{array}$ \\
\hline Q3 & $\begin{array}{l}\text { Do you store process and product measures in } \\
\text { the measurement repository of the } \\
\text { organization? }\end{array}$ & $\begin{array}{l}\text { - Storing process and product measures in the } \\
\text { measurement repository of the organization. } \\
\text { inclusion in the process asset library of the } \\
\text { organization? } \\
\text { (Examples of documentations: exemplary } \\
\text { process description, training modules, } \\
\text { exemplary plans, templates, and tool } \\
\text { configurations). }\end{array}$ \\
\hline
\end{tabular}

\subsection{Measures for specific practice 8 .}

Manage Stakeholder Involvement: Manage the participation of relevant stakeholders in the project.

Questions and measures which are given in the following table related to specific practice 8 in IPM.

Table 8. Questions and measures related to practice 8 in IPM.

\begin{tabular}{|c|c|c|}
\hline & Questions & Measures \\
\hline Q1 & $\begin{array}{l}\text { Do you manage the participation of relevant } \\
\text { stakeholders in the project according to the } \\
\text { integrated plan of the project and defined } \\
\text { process? }\end{array}$ & $\begin{array}{l}\text { - Managing the participation of relevant } \\
\text { stakeholders. } \\
\text { - \# Relevant stakeholders. }\end{array}$ \\
\hline $\mathrm{Q} 2$ & $\begin{array}{l}\text { Do you range with relevant stakeholders who } \\
\text { should cooperate in the project activities? }\end{array}$ & $\begin{array}{l}\text { - Coordinating with relevant stakeholders. } \\
\text { - \# Relevant stakeholders coordinated with. }\end{array}$ \\
\hline Q3 & $\begin{array}{l}\text { Do you ensure that the produced work } \\
\text { products meet the requirements of the } \\
\text { recipients? }\end{array}$ & $\begin{array}{l}\text { - Ensuring that the produced work products } \\
\text { meet the requirements of the recipients. } \\
\text { - \# produced work products. }\end{array}$ \\
\hline $\mathrm{Q} 4$ & $\begin{array}{l}\text { Do you review, demonstrate or test as } \\
\text { appropriate each work product produced by } \\
\text { the project? }\end{array}$ & $\begin{array}{l}\text { - Reviewing, demonstrating or testing as } \\
\text { appropriate each work product. } \\
\text { - \# Work product. }\end{array}$ \\
\hline Q5 & $\begin{array}{l}\text { Do you resolve issues related to the } \\
\text { acceptance of the work products? }\end{array}$ & $\begin{array}{l}\text { - Resolving issues related to the approval of } \\
\text { the work products. } \\
\text { - \# Work product }\end{array}$ \\
\hline Q6 & $\begin{array}{l}\text { Do you develop recommendations and actions } \\
\text { to resolve misunderstandings and problems } \\
\text { with requirements? }\end{array}$ & $\begin{array}{l}\text { - Developing recommendations and actions to } \\
\text { resolve misunderstandings and problems } \\
\text { with requirements. } \\
\text { - \# Misunderstandings Requirements. } \\
\text { - \# Requirements with problems. }\end{array}$ \\
\hline
\end{tabular}


International Journal of Computer Science \& Information Technology (IJCSIT) Vol 7, No 5, October 2015

\subsection{Measures for specific practice 9.}

Manage Dependencies: cooperate with relevant stakeholders to negotiate, identify, and track critical dependencies.

Questions and measures which are given in the following table related to specific practice 9 in IPM.

Table 9. Questions and measures related to practice 9 in IPM.

\begin{tabular}{|c|c|c|}
\hline & Questions & Measures \\
\hline Q1 & $\begin{array}{l}\text { Do you participate with relevant stakeholders } \\
\text { to identify, negotiate and track critical } \\
\text { dependencies? }\end{array}$ & $\begin{array}{l}\text { - Cooperate with relevant stakeholders to } \\
\text { negotiate, identify, and track critical } \\
\text { dependencies. } \\
\text { - \# Critical dependencies. }\end{array}$ \\
\hline Q2 & $\begin{array}{l}\text { Do you conduct reviews with relevant } \\
\text { stakeholder? }\end{array}$ & $\begin{array}{l}\text { - Conducting reviews with relevant } \\
\text { stakeholder. } \\
\text { - \# Relevant stakeholder. }\end{array}$ \\
\hline Q3 & Do you identify each critical dependency? & $\begin{array}{l}\text { - Identifying each critical dependency. } \\
\text { - \# Critical dependencies. }\end{array}$ \\
\hline $\mathrm{Q} 4$ & $\begin{array}{l}\text { Do you establish need dates and plan dates for } \\
\text { each critical dependency? }\end{array}$ & $\begin{array}{l}\text { - Establishing plan dates and need dates for } \\
\text { each critical dependency. }\end{array}$ \\
\hline Q5 & $\begin{array}{l}\text { Do you review and obtain approval on } \\
\text { commitments to address for each critical } \\
\text { dependency? }\end{array}$ & $\begin{array}{l}\text { - Reviewing and obtaining approval on } \\
\text { commitments to address for each critical } \\
\text { dependency. } \\
\text { - \# Reviewed Critical dependencies. }\end{array}$ \\
\hline Q6 & $\begin{array}{l}\text { Do you document for critical dependencies } \\
\text { and commitments? }\end{array}$ & $\begin{array}{l}\text { - Documenting for critical dependencies and } \\
\text { commitments. } \\
\text { - \# documented Critical dependencies. }\end{array}$ \\
\hline Q7 & $\begin{array}{l}\text { Do you track critical dependencies and } \\
\text { commitments and take corrective action? }\end{array}$ & $\begin{array}{l}\text { - Tracking critical dependencies and } \\
\text { commitments and take corrective action. } \\
\text { - \# Corrective actions. }\end{array}$ \\
\hline Q8 & $\begin{array}{l}\text { Do you escalate to the suitable party the actual } \\
\text { and potential problems not solvable by the } \\
\text { responsible individual or group? }\end{array}$ & $\begin{array}{l}\text { - Escalating to the suitable party the actual and } \\
\text { potential problems not solvable. } \\
\text { - \# Actual and potential irresolvable problems. }\end{array}$ \\
\hline Q9 & $\begin{array}{l}\text { Do you evaluate the effects of the late and } \\
\text { early completion on future activities and } \\
\text { milestones? }\end{array}$ & $\begin{array}{l}\text { - Evaluating the effects of the late and early } \\
\text { completion on future activities and } \\
\text { milestones. } \\
\text { - \# Future activities. } \\
\text { - \# Milestones. }\end{array}$ \\
\hline
\end{tabular}

\subsection{Measures for specific practice 10.}

Resolve Coordination Issues: Resolve issues with relevant stakeholders.

Questions and measures which are given in the following table related to specific practice 10 in IPM. 
Table 10. Questions and measures related to practice 10 in IPM.

\begin{tabular}{|c|c|c|}
\hline & Questions & Measures \\
\hline Q1 & $\begin{array}{l}\text { Do you resolve issues with relevant } \\
\text { stakeholders? (Issues examples include: } \\
\text { product component requirements, critical } \\
\text { dependencies, and unavailability to critical } \\
\text { resources or staff)? }\end{array}$ & $\begin{array}{l}\text { - Resolving issues with relevant stakeholders. } \\
\text { - \# issues with relevant stakeholders. }\end{array}$ \\
\hline Q2 & Do you identify or document issues? & $\begin{array}{l}\text { - Identifying or documenting issues. } \\
\text { - \# Identified issues. } \\
\text { - \# Documented issues. }\end{array}$ \\
\hline Q3 & $\begin{array}{l}\text { Do you communicate and resolve issues with } \\
\text { relevant stakeholders? }\end{array}$ & $\begin{array}{l}\text { - Communicating and resolving issues with } \\
\text { relevant stakeholders. } \\
\text { - \# Resolved issues. } \\
\text { - \# Relevant stakeholders with each issue. }\end{array}$ \\
\hline Q4 & $\begin{array}{l}\text { Do you escalate the issues not resolvable to } \\
\text { appropriate managers? }\end{array}$ & $\begin{array}{l}\text { - Escalating the issues not resolvable to } \\
\text { appropriate managers. } \\
\text { - \# Issues not resolvable. }\end{array}$ \\
\hline Q5 & Do you track issues to closure? & $\begin{array}{l}\text { - Tracking issues to closure. } \\
\text { - \# Tracked issues to closure. }\end{array}$ \\
\hline
\end{tabular}

\section{Validity and Reliability Of The Defined Measures}

A questionnaire has been made to examine the validity and reliability of the defined measures for Integrated Project Management process (IPM) area and confirm that they are actually measure the ten specific practices. We will test the data we have collected using cronbach alpha reliability in SPSS.

The questionnaire which we used was reviewed and confirmed by academics and practitioners in software building in software engineering in Zarqa University. Software developers, designers, and students in software engineering departments filled the questionnaire. The questionnaire consists of ten parts, each paet is related to one of the ten specific practices of the Integrated Project Management process area (IPM), each section consists of a group of statements (measures) related to a specific practice, each statement has five options: strongly agree, agree, neither agree nor disagree, disagree, strongly disagree. When a questioner reads the statement he will write his view of the statement related to the specific practice by selecting one of the available five options, a sample shown in Appendix A.

The tool Cronbach alpha is used to measure the internal consistency. Which means, do all items measure the same thing? (Measure a single unidirectional structure). Cronbach alpha values are varying between 0 and 1 . A large internal consistency of items being assessed if alpha is closer to 1 [12]. If Cronbach alpha value is less than 0.5 then internal consistencies is rejected [12]. After applying the collected data on Cronbach Alpha we found that alpha values between over 0.5 and less than 1.

\section{CONCLUSION}

This paper defined general measures for Integrated Project Management process (IPM) process area in Capability Maturity Model Integration (CMMI-SW) for software development. This paper defined the measures by applying the Goal Question Metrics (GQM) method to the two specific goals and its ten specific practices of Integrated Project Management process area PA. This paper 
concentrated on defining measures for a particular process area rather than defining measures for group of process areas.

The set of measures which were defined in this paper provide the organization with better insight into the activities related to Integrated Project Management (IPM) process area and enhance the development of software to the object of having a matured process. The set of measures can be used to evaluate and control software products and processes. The Use of the defined measures determines by the software development process maturity in the organization.

\section{REFERENCES}

[1] Basili, V. R. and Rombach, H. D., "The TAME Project: Towards Improvement-Oriented Software Environments", in IEEE Transactions on Software Engineering, vol. 14, no. 6, pp.758-773, 1988.

[2] Basili, V. R., Caldiera, C., Rombach, H. D., Goal Question Metric Paradigm, Encyclopedia of Software Engineering (Marciniak, J.J., editor), volume 1, John Wiley \& Sons, pp. 528-532, 1994.

[3] Basili, V. R., and Weiss, D. M., "A Methodology for collecting Valid Software Engineering Data", in IEEE Transactions on Software Engineering, volume. SE-10, pp.728-738, 1984.

[4] Baumert, J. H. and McWhinney, M. S., Software Measures and the Capability Maturity Model, Software Engineering Institute Technical Report, CMU/SEI-92-TR-25, ESC-TR-92-0, 1992.

[5] Briand, L.C., Morasca, S., and Basili, V. R., "An Operational Process for Goal Driven Definition of Measures", in IEEE Transactions on Software Engineering, vol. 28, no. 12, 2002.

[6] Ebert, C. , Software Measurement for Better Project and Process Quality, UPGRADE (the European Journal for the Informatics Professional), Vol. x, No. 5, October, 2009.

[7] Ejiogu, L. O., " Five Principles for the Formal Validation of Models of Software Metrics “, ACM SIGPLAN Notices, Vol. 28,No. 8, August 1993.

[8] Fenton, N.E., and Pfleeger, S.L., Software Metrics - A Rigorous \& Practical Approach, 2nd Edition, International Thomson Publishing, Boston, MA, 1996.

[9] Fenton, N. E. \& Whitty, R. and Yoshinori, I. Software Quality Assurance and Measurement, A Worldwide Perspective. London: International Thomson Computer Press, 1995.

[10] Ferrucci, F., Harman, M. and Sarro, F.,Search-Based Software Project Management, in Software Project Management in a changing world, Gunther Ruhe and Claes Wholin(Editors), Springer, 2014.

[11] Filipe, J., Shishkoy, B., Helfert, M. (Eds.): A Systematic Review Measurement in Software Engineering: State-of-the-Art in Measurement, RICSOFT 2006, CCIS vol. 10, pp. 165-176, 2008.@ Springer-Verlag Berlin Heidelberg 2008.

[12] George, D. and Mallery, P., SPSS for windows step by step A Simple Guide and Reference, Fourth Edition, 2003.

[13] Hammer T. F., Huffman L. L., and Rosenberg L. H, "Doing requirements right the first time", in CROSSTALK, The Journal of Defence Software Engineering, December, pp. 20-25, 1998.

[14] Hwang, B. and Ng, W, Project Management Knowledge and Skills for Green Construction: Overcoming Challenges, International Journal of Project Management, Vol. 31, Iss. 2, February 2013, pp. 272-284.

[15] Jacquet, J. P. and Abran, A., "Metric Validation Proposals, A structured Analysis", 8th International Workshop on Software Measurement, Germany, Sept. 17-18, 1998.

[16] Janakiram. D and Rajasree. M. S, "ReQuEst: Requirements-driven Quality Estimator", in ACM SIGSOFT Software engineering notes, vol. 30, no.1, 2005.

[17] Jones, C. , Implementing a Successful Measurement Program: Tried and True Practices and Tools, Cutter IT Journal, Vol. 11, No. 5, November, 2003.

[18] Z. D. Kelemen, R. Kusters, J. Trienekens, and K. Balla, "Towards Complexity Analysis of Software Process Improvement Frameworks,” Budapest, Technical Report TR201301, Sep. 2013.

[19] Khraiwesh, M., Requirements Validation Measures in CMMI, Mahmoud Khraiwesh, World of Computer Science and Information Technology Journal (WCSIT), Vo.1, No. 2, 26-33, 2011.

[20] Khraiwesh, M., Risk Management Measures in CMMI, International Journal of Software Engineering \& Applications (IJSEA), Vo. 3, No. 1, 149-163, January 2012.

[21] Khraiwesh, M., Project Planning Measures in CMMI, International Journal of Software Engineering \& Applications (IJSEA), Vo. 4, No. 2, 103-121, March 2013. 
[22] Khraiwesh, M., Project Monitoring and Control in CMMI, Project Monitoring and Control Measures in CMMI, International Journal of Computer Science \& Information Technology (IJCSIT) Vol. 5, No. 5, October 2013.

[23] Khraiwesh, M., Process and Product Quality Assurance Measures in CMMI, International Journal of Computer Science and Engineering Survey (IJCSES), Vol. 5, No. 3, June. 2014.

[24] Kitchenham, B., Pfleeger, S.L., and Fenton, N., Towards a Framework for Software Measurement Validation, in IEEE Transactions on Software Engineering, 21(12), December 1995.

[25] Kitchenham, B., Jeffery, D. and Connaughton, C., Misleading Metrics and Unsound Analyses, IEEE Software, April 2007, Vol. 24, No. 2, pp. 73-78.

[26] Kloppenborg, T., Contemporary Project Management, third edition, Cengage learning, USA, 2014.

[27] Lee, Y, and Chen, J. Experience in introducing CMM to a telecommunication research organization, Journal of Software Engineering Studies, vol.1, No. 1, 8-16, September 2006.

[28] Loconsole, A., "Measuring the Requirements Management Key Process Area", Proceedings of ESCOM - European Software Control and Metrics Conference, London, UK, April, 2001.

[29] Mahinc, V. and Zabkar, N. Measurement repository for Scrum-based software development process. Conference on computer Engineering and Application (CEA,08) Acapulco, Mexico, January 25-27, 2008.

[30] Monterio, P., Machado, R., Kazman, R., Simoes, C., and Ribeiro, P.,RUP Alignment and Coverage Analysis of CMMI ML2 Process Areas for the Context of Software Project Execution, 6th International Conference, SWQD, 2014, Vienna, Austria, January 14-16, 2014, Proceedings.

[31] Park, R. E., Goethert, W. B. and Florac, W. A., Goal-Driven Software Measurement-A Guidebook, Software Engineering Institute Handbook, CMU/SEI-96- HB-002, August, 1996.

[32] Paulk, M. C., Weber, C. V., Garcia, S., Chrissis, M. B., and Bush, M., Key Practices of the Capability Maturity Model Version 1.1, Software Engineering Institute Technical Report, CMU/SEI-93- TR-25 ESC-TR-93-178, Pittsburgh, PA, USA, February, 1993.

[33] Pressman, R. S., Software engineering: A practitioner's Approach, Sixth edition, 2005.

[34] Pyster A., What Beyond CMMI Is needed to Help Assure Program and Project Success, SPW 2005, LNCS 3840, pp. 75 - 82, 2005. (C) Springer-Verlag Berlin Heidelberg 2005.

[35] SEI (software Engineering Institute), CMMI (Capatility Maturity Model-Integrated) for development, V 1.3, Carnegie Mellon University, November 2010.

[36] Spalek, S., Does Investment in Project Management Pay off, Industrial Management \& Data Systems, Vol. 114, Iss. 5, pp. 832 - 856, 2014.

[37] Wang, X., Liu, L., and Wei, Y., Emerging Technologies for Information Systems, Computing, and Management, pp 1261-1268, Springer, 2013.

[38] Wu, C. S. , Simmons D. B., Software project planning Associate(SPPA): a knowledge based approach for dynamic software project planning and tracking, 24th International Computer Software and Application conference, (COMPSAC), Taiwan, October, 2000.

[39] Xiong W., and Cao Y., Comments on Software Process Improvement Methodologies Using QFD, Applied Mathematics \& Information Sciences Journal, Vol. 7, No. 3, 1137-1143, 2013.

[40] Xu, G., Univ, N., China, N., Hu, H., Yu, P., and Lv, J., Supporting Flexibility of the CMMI Process Framework with a Multi-layered Process Model, Web Information System and Application Conference (WISA), 2013 10th, 10-15 Nov., 2013, IEEE.

[41] Young, H., Fang, T., and Hu, C. A successful practice of applying software tools to CMM1 process improvement, Journal of Software Engineering Studies, Vol. 1, No. 2, 78-95, December 2006.

\section{Appendix A}

\section{Questionnaire and Analysis}

\section{Questionnaire:}

This questionnaire is related to the Integrated Project Management process. Integrated Project Management process provides an understanding of the proceeding in the project so that suitable corrective actions can be taken when the project deviates clearly from the plan.

The Integrated Project Management process has 10 goals: 
1- Establish the Project's Defined Process.

2- Use Organizational Process Assets for Planning Project Activities.

3- Establish the Project's Work Environment.

4- Integrate Plans.

5- Manage the Project Using Integrated Plans.

6- Establish Teams.

7- Contribute to Organizational Process Assets.

8- Manage Stakeholder Involvement.

9- Manage Dependencies.

10- Resolve Coordination Issues.

We will measure the achievement of the above goals (specific practices), thus, we define some sentences related to each goal. We suppose that the information in these sentences help us in achievement of the above ten goals.

Please, fill this form by writing down $\sqrt{ }$ in the proper place. Replying to the question: do you think that the sentences have an effect on the achievement of the goals (specific practices)?

1. Goal1: Establish the Project's Defined Process.

(Do you think that these sentences have an impact on the achievement of goal1: Establish the Project's Defined Process.)

\begin{tabular}{|c|c|c|c|c|c|c|}
\hline $\begin{array}{l}\text { statement } \\
\text { serial }\end{array}$ & statements & $\begin{array}{l}\text { Strongly } \\
\text { agree }\end{array}$ & Agree & $\begin{array}{l}\text { Neither } \\
\text { agree nor } \\
\text { disagree }\end{array}$ & disagree & $\begin{array}{l}\text { Strongly } \\
\text { disagree }\end{array}$ \\
\hline 1 & $\begin{array}{l}\text { Establishing and } \\
\text { maintaining the } \\
\text { defined process of } \\
\text { the project. }\end{array}$ & & & & & \\
\hline 2 & $\begin{array}{l}\text { Defining the project } \\
\text { processes based on } \\
\text { stakeholder } \\
\text { requirements. }\end{array}$ & & & & & \\
\hline 3 & $\begin{array}{l}\text { Defining the project } \\
\text { processes based on } \\
\text { standard processes. }\end{array}$ & & & & & \\
\hline 4 & $\begin{array}{l}\text { Defining the project } \\
\text { processes based on } \\
\text { business } \\
\text { environment and } \\
\text { operational } \\
\text { environment. }\end{array}$ & & & & & \\
\hline 5 & $\begin{array}{l}\text { Elaborating and } \\
\text { revising the defined } \\
\text { processes as the } \\
\text { project progresses. }\end{array}$ & & & & & \\
\hline
\end{tabular}


International Journal of Computer Science \& Information Technology (IJCSIT) Vol 7, No 5, October 2015

\section{AUTHORS}

Mahmoud khraiwesh is an associate professor at Faculty of Information Technology in Zarqa University, Jordan. He got his master degree in computer science from Jordan University, Jordan, in 2002 and his doctorate degree in computer information system from The Arab Academy for Banking and Financial sciences, Jordan, in 2006. Dr. Khraiwesh area of research is in software development measures

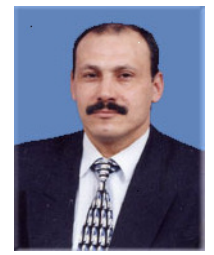

